\title{
Annual cycle of microalgal biomass in a South African temporarily-open estuary: nutrient versus light limitation
}

\author{
Christian Nozais $^{1, *}$, Renzo Perissinotto ${ }^{1, * *}$, Sarasvathi Mundree $^{2}$ \\ ${ }^{1}$ School of Life and Environmental Sciences, G. Campbell Building, University of Natal, King George V Avenue, \\ Durban 4041, South Africa \\ ${ }^{2}$ Marine Science Unit, University of Durban-Westville, Private Bag X54001, Durban 4000, South Africa
}

\begin{abstract}
The vast majority (73\%) of South African estuaries are temporarily-open systems. There is virtually no information available on their trophic functioning, particularly at the lower levels of the food web. A whole-year survey was carried out to investigate variations in the biomass of phytoplankton and microphytobenthos in relation to major factors potentially controlling their dynamics in a subtropical temporarily-open estuary. Microphytobenthic chlorophyll a (chl a) concentrations ranged from 75 to $480 \mathrm{mg} \mathrm{m}^{-2}$, while phytoplankton biomass varied between 0.09 and $8.6 \mathrm{mg} \mathrm{chl} a$ $\mathrm{m}^{-3}$. Areal chl a concentrations in the sediment (microphytobenthos) were typically 1 to 2 orders of magnitude higher than in the water column (phytoplankton). The vertical attenuation coefficient in the water, $K_{\mathrm{d}}$, varied between 0.94 and $28.9 \mathrm{~m}^{-1}$. Dissolved inorganic nitrogen to phosphorus molar ratios (DIN:DIP) varied between 0.3 and 127. The results suggest that nutrients rather than light might have limited phytoplankton growth during the closed phase of the estuary, since $K_{\mathrm{d}}$ values were lowest during this period. On the other hand, light rather than nutrients might have limited phytoplankton growth during the open phase, since nutrient concentrations in the water column were very low prior to the opening of the estuary at the mouth. The marked increase in phytoplankton biomass at the onset of the open phase further supports the hypothesis that phytoplankton cells might have been nutrient-limited during the closed phase. Resuspension by freshwater inflow may have also contributed to this increase. Microphytobenthic standing stock exhibited strong seasonal fluctuations, with the lowest values coinciding with the open phase. However, unlike phytoplankton, benthic microalgal biomass did not appear to be inhibited by either low nutrients or light availability.
\end{abstract}

KEY WORDS: Temporarily-open estuary $\cdot$ Phytoplankton $\cdot$ Microphytobenthos $\cdot$ Chlorophyll a Nutrients $\cdot$ Light

Resale or republication not permitted without written consent of the publisher

\section{INTRODUCTION}

The continuing degradation of South African estuaries, due to a growing human population and to industrial development, is increasing the scientific and managerial interest in their ecological functioning (Whit-

\footnotetext{
* Present address: Institut des Sciences de la Mer de Rimouski (ISMER), Université du Québec à Rimouski, 310 Allée des Ursulines, Rimouski, Québec GSL 3AI, Canada.

${ }^{* *}$ Corresponding author. E-mail: renzo@biology.und.ac.za
}

field 1995, Allanson \& Baird 1999, Morant \& Quinn 1999). To date, most studies have been carried out in large open estuaries because of their capability for high productivity and biodiversity (Allanson et al. 1999). On the other hand, temporarily-open estuaries that account for $73 \%$ of the total number of South African estuarine systems have been given little consideration (Whitfield 1995). These systems are closed off from the sea during the dry season and experience low or no river inflow conditions combined with longshore sand movement in the marine nearshore (Day 
1981, Whitfield 1992). Following periods of high rainfall and freshwater runoff, the water level inside these estuaries rises gradually until it exceeds the height of the sandbar at the mouth. Breaching then occurs and the water level drops very rapidly, often exposing large areas of substrate which had been previously submerged and colonised by a rich community of plants and animals (Perissinotto et al. 2000, Walker et al. in press).

Compared to their permanently-open counterparts, temporarily-open estuaries are much more susceptible to accumulation of pollutants (Begg 1984). Also, retention of freshwater by dams for industrial, agricultural and domestic purposes has led to a reduction of both the frequency and duration of mouth-opening (Reddering \& Rust 1990).

During the past few decades, a great deal of progress has been made in South Africa towards the understanding of the population dynamics of primary and secondary consumers of temporarily-open estuaries (Blaber et al. 1984, Forbes et al. 1994, de Villiers et al.

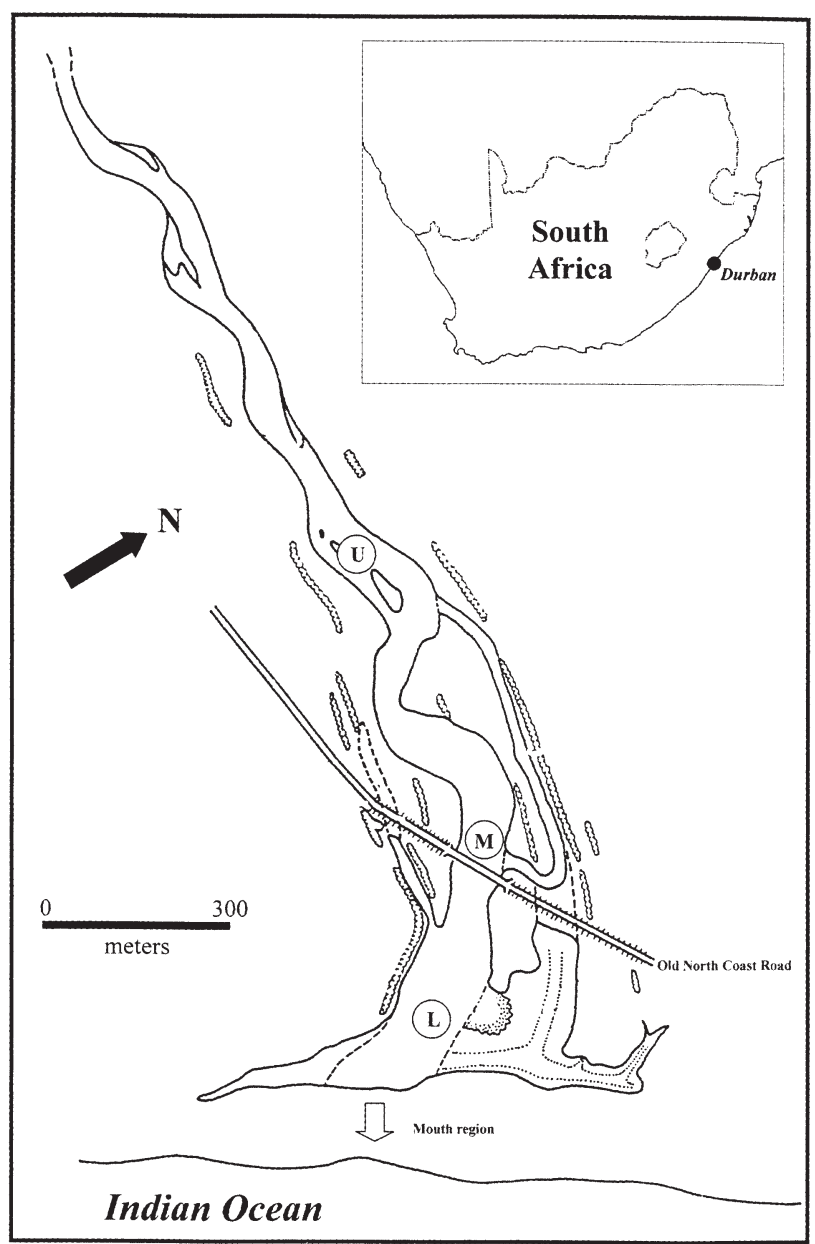

Fig. 1. Map of the Mdloti Estuary with sampling stations. Latitude and longitude at the mouth $=29^{\circ} 38^{\prime} \mathrm{S}, 31^{\circ} 08^{\prime} \mathrm{E}$
1999, Whitfield \& Marais 1999). On the other hand, investigations dealing with the dynamics of the main primary producers (i.e. phytoplankton and sedimentassociated microalgae or microphytobenthos) inhabiting temporarily-open estuaries are still very scarce. Yet, primary producers have a crucial ecological function, since they provide a link between inorganic compounds and organic matter available to higher trophic levels and top predators (Miller et al. 1996, Mortazavi et al. 2000).

The few investigations carried out in South African estuaries have shown that microphytobenthic biomass can be higher in temporarily than in permanentlyopen estuaries and also much greater than phytoplankton biomass (Adams et al. 1999, Snow et al. 2000a,b, Walker et al. in press). Moreover, Perissinotto et al. (2001) reported that major changes in phytoplankton and microphytobenthic standing stocks are strongly related to the alternation of open and closed phases of temporarily-open estuaries. The environmental factors that trigger these changes, however, have not been identified because of the complex interactions existing between nutrients, irradiance and water circulation in their control of microalgal dynamics, and because of the large sampling intervals usually involved in these studies.

The aim of this study was, therefore, to expand the investigations by covering a higher sampling frequency of phytoplankton and microphytobenthic biomass as well as a wider range of physical and chemical parameters. Potential relations between chl $a$ and abiotic factors were then assessed over a 12 mo period in a temporarily-open estuary with a strongly riverine character.

\section{MATERIALS AND METHODS}

This study was conducted in the Mdloti Estuary, situated on the Kwazulu-Natal north coast $\left(29^{\circ} 38^{\prime} \mathrm{S}\right.$, $\left.31^{\circ} 08^{\prime} \mathrm{E}\right), 25 \mathrm{~km}$ north east of Durban (Fig. 1). Three stations (L: lower reaches; M: middle reaches; and U: upper reaches) were sampled at regular monthly intervals from May 1999 to April 2000.

Microalgal biomass was estimated as chl a concentration. Water samples for phytoplankton chl a determination were collected $10 \mathrm{~cm}$ below the surface and $30 \mathrm{~cm}$ above the bottom, using a $500 \mathrm{ml}$ polyethylene bottle and a $1000 \mathrm{ml}$ weighted pop-bottle, respectively. Aliquots of $100 \mathrm{ml}$ were filtered through GF/F glassfiber filters, and pigments were extracted immediately in polyethylene tubes with $10 \mathrm{ml}$ of $90 \%$ acetone.

Sediment samples for microphytobenthic chl a determination were collected using a Perspex twin-corer of $20 \mathrm{~mm}$ internal diameter, following the recommenda- 
tions of Rodriguez (1993) for South African estuaries. Following the methodology previously employed by other researchers in the area, 3 core samples were taken on each occasion and at each station. The top first centimeter of the sediment was cut off and placed in a $50 \mathrm{ml}$ polyethylene bottle with $30 \mathrm{ml}$ of $90 \%$ acetone for the extraction of pigments. All chl a concentrations were measured using a 10-AU Turner Designs fluorometer fitted with the narrow-band, non-acidification system of Welschmeyer (1994). This system allows precise measurements (maximum $10 \%$ error) of chl $a$ without interference from other photosynthetic pigments or their degradation products (Welschmeyer 1994). Calibrations were made using pure extracts of chl a from Anacystis nidulans algae (Sigma Products).

Water samples for the determination of dissolved inorganic nitrogen, DIN $\left(\mathrm{NO}_{2}{ }^{-}, \mathrm{NO}_{3}{ }^{-}\right.$, and $\left.\mathrm{NH}_{4}{ }^{+}\right)$, and dissolved inorganic phosphorus, DIP, were obtained from the same water samples collected for phytoplankton chl a analysis, and placed in $500 \mathrm{ml}$ acid prewashed polyethylene bottles. Nutrient concentrations were later determined from triplicate sub-samples using a Technicon Autoanalyzer II system and following the methods of Mostert (1983).

At each station, a vertical profile of downwelling irradiance (PAR, 400 to $700 \mathrm{~nm}$ ) was measured with a LI-COR LI-189 underwater quantum sensor. A relative measure of light penetration into natural waters, using downward irradiance measurements recorded at different depths, is the diffusive attenuation coefficient, $K_{\mathrm{d}}$ (Kirk 1983). $K_{\mathrm{d}}\left(\mathrm{m}^{-1}\right)$ was estimated using the relation:

$$
K_{\mathrm{d}}=-\ln \left(I_{z_{2}} / I_{z_{1}}\right) / z_{2}-z_{1}
$$

where $I_{z_{2}}=$ irradiance $\left(\mu \mathrm{mol} \mathrm{m} \mathrm{m}^{-2} \mathrm{~s}^{-1}\right)$ at depth $z_{2}(\mathrm{~m})$, $I_{z_{1}}=$ irradiance at depth $z_{1}\left(z_{2}>z_{1}\right.$, i.e. $z$ increases positively downward).

Temperature and salinity were recorded on each occasion using a YSI 6920 water logger. Daily precipitation data $(\mathrm{mm})$ were provided by the South African Sugar Association Experiment Station, Durban.

A 1-way ANOVA was run to test for differences in phytoplankton (surface and bottom samples, separately) chl a concentrations between sampling dates. Differences in microphytobenthic chl a concentrations between sampling dates and stations were examined using a 2-way ANOVA. Prior to the analysis, variables were $\log _{10}$-transformed to comply with the assumptions of the various parametric tests employed. A Tukey's multiple comparison of means was used when significant differences $(p<0.05)$ were found between sets of means. Spearman and partial rank-correlation analyses were also performed between rainfall and estuarine physical, chemical and biological response variables using the entire data set.
Vertically-integrated water-column chl a concentrations were calculated for each station by averaging the surface and bottom chl a values and multiplying the average by total actual water depth. A Mann-Whitney $U$-test was performed to investigate potential differences in the ratio of the relative areal concentration of microphytobenthos to phytoplankton chl a between the open and closed phases of the estuary. All statistical analyses were carried out using the SPSS 9.0 package.

\section{RESULTS}

Highly seasonal but erratic rainfall occurred during the survey (Fig. 2): $62.7 \%$ was observed in summer between November 1999 and April 2000, with a maximum of $37.4 \mathrm{~cm}$ in December 1999 and a minimum of $4.7 \mathrm{~cm}$ in April 2000. The total rainfall in the Mdloti Estuary was $58.8 \mathrm{~cm}$ during the winter and $98.7 \mathrm{~cm}$ during the summer. The estuary was closed between May and October 1999. During this period the average depth of the water column was $1.9 \mathrm{~m}$. Mouth-breaching occurred on 16 November 1999, 1 wk prior to the survey, and the consequent drainage resulted in a dramatic drop in the average depth of the estuary to $0.6 \mathrm{~m}$. This situation persisted until the end of the survey.

Surface irradiance varied widely during the survey period as a result of cloud cover and seasonal trends. Maximum and minimum surface intensities attained levels of 2020 and $189 \mu \mathrm{mol} \mathrm{m}^{-2} \mathrm{~s}^{-1}$, respectively. During the closed phase of the estuary, $K_{\mathrm{d}}$ varied between
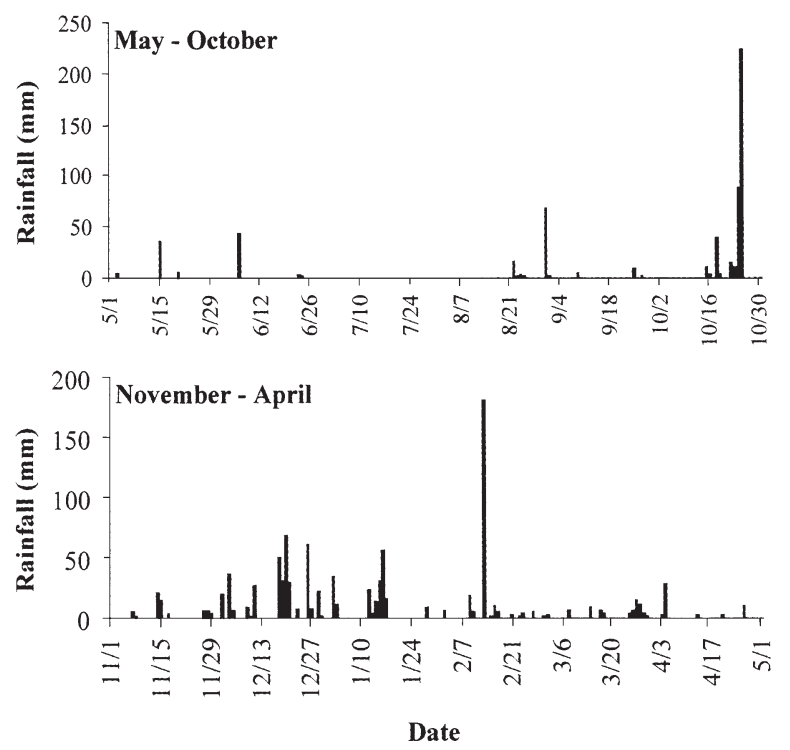

Fig. 2. Precipitation data for the Mdloti Estuary during the survey period (closed phase: May 1999 to October 1999; open phase: November 1999 to April 2000). Abscissas show month/day 


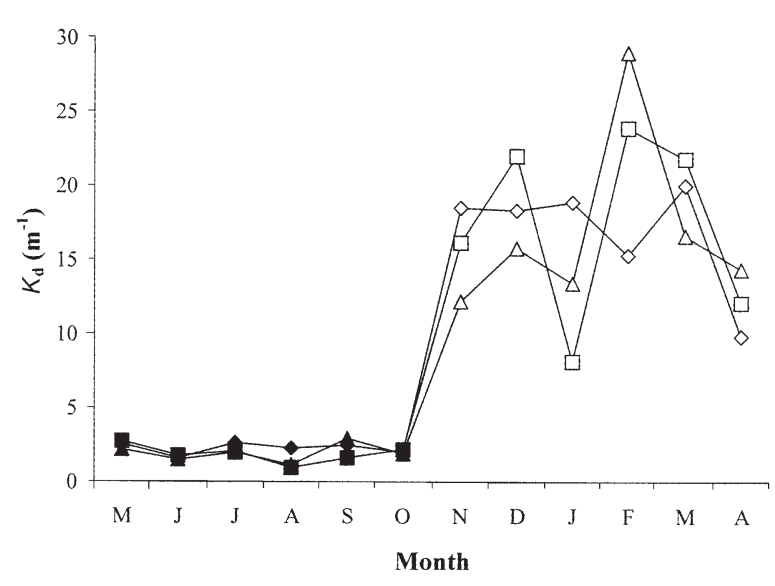

Fig. 3. Temporal variations of $K_{\mathrm{d}}$ at Stns L ( $\square$ : closed phase; ๑: open phase), M ( $\bullet$ : closed phase; $\diamond$ : open phase), and U

$(\mathbf{\Delta}$ : closed phase; $\Delta$ : open phase) in the Mdloti Estuary

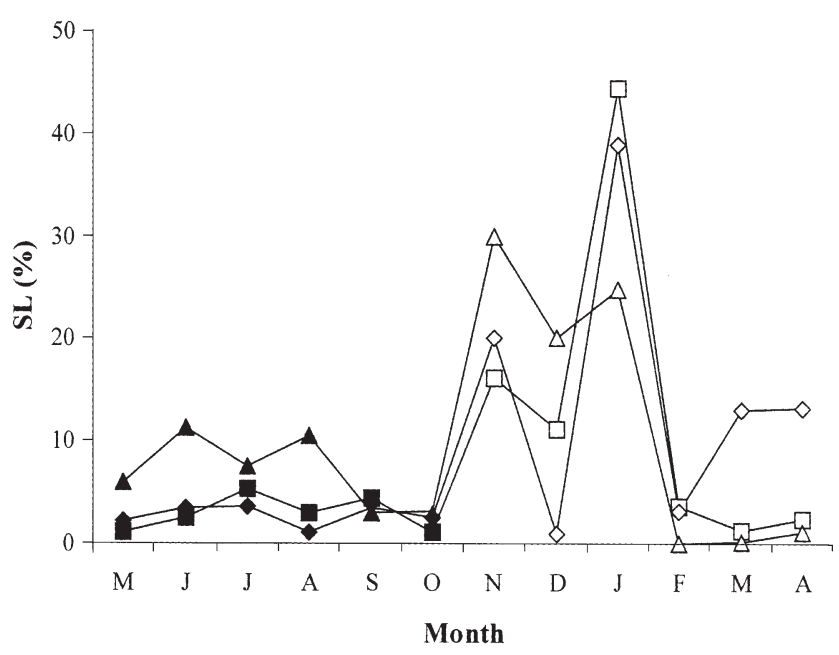

Fig. 4. Temporal variations in the percentage of surface light (SL) recorded at the sediment/water interface at Stns L, M and $\mathrm{U}$ in the Mdloti Estuary. Symbols as in Fig. 3

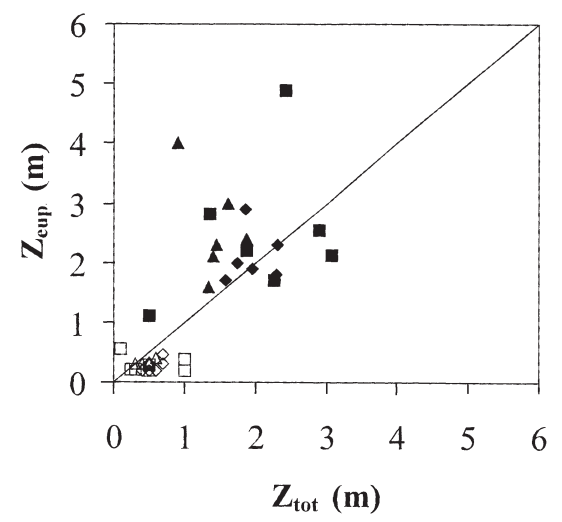

Fig. 5. Euphotic depth $\left(Z_{\text {eup }}\right)$ versus water depth $\left(Z_{\text {tot }}\right)$ at Stns L, M and U in the Mdloti Estuary. Symbols as in Fig. 3. Line represents 1:1 relationship
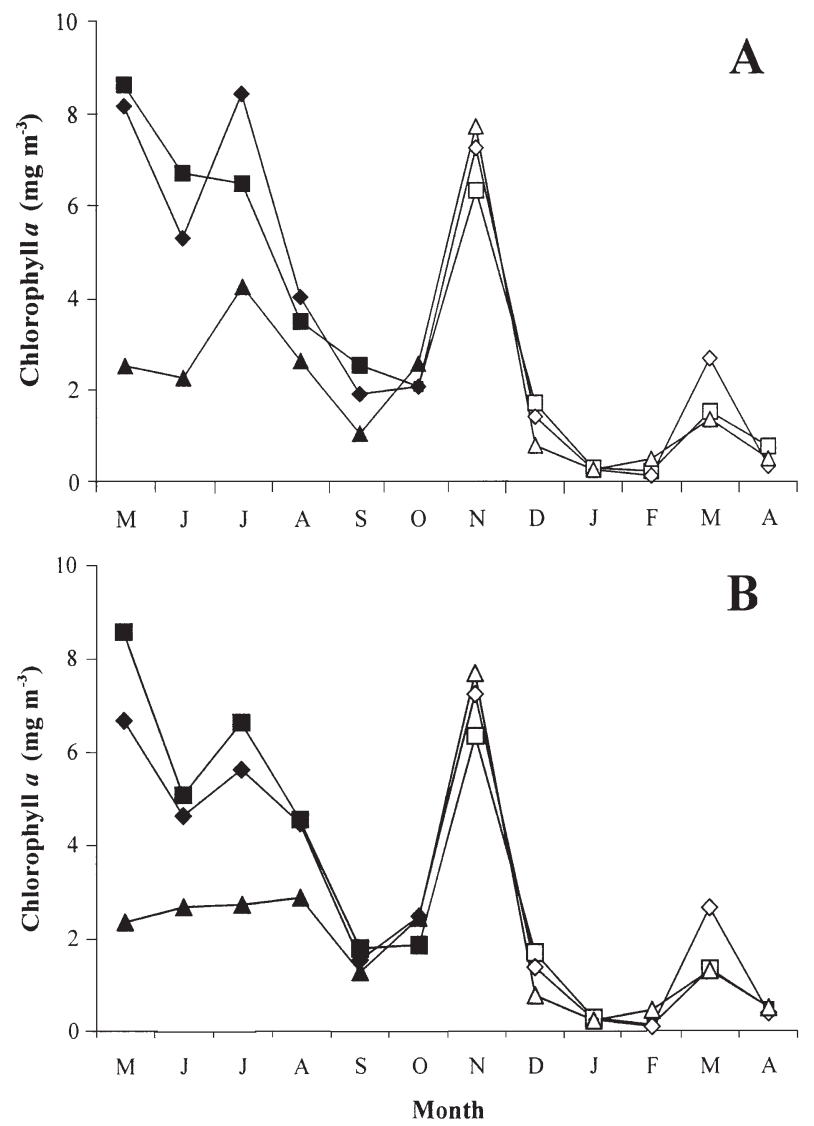

Fig. 6. Temporal variations in surface (A) and bottom (B) phytoplankton biomass at Stns L, M and U in the Mdloti Estuary. Symbols as in Fig. 3

0.94 and $2.95 \mathrm{~m}^{-1}$ (Fig. 3), with 1.04 to $11.3 \%$ of the surface light intensity reaching the bottom of the water column (Fig. 4). Conversely, when the opening of the estuary led to heavy silt loading and a dramatic increase in turbidity levels, $K_{\mathrm{d}}$ ranged from 8.14 to $28.9 \mathrm{~m}^{-1}$. Turbidity combined with the shallowness of the water column resulted in a varying surface light intensity reaching the bottom (from 0.01 to $44.3 \%$ ). Due to the high concentration of silt particles in the water column, the depth of the euphotic zone, $Z_{\text {eup }}$ dropped to values much shallower than the estuary's total depth, with only 1 exception, in January 2000 (Fig. 5).

Water temperature changed slightly with season, ranging from 16 to $21^{\circ} \mathrm{C}$ in winter and from 22 to $29^{\circ} \mathrm{C}$ in summer. Because of the low and irregular sea-water supply received by the Mdloti Estuary from the adjacent coastal area during the study period, salinity levels were extremely low all year round. Salinity typically ranged from 0.1 to 0.6 in winter and from 0.5 to 9.6 in summer. Highest levels usually occurred at Stn L and during the open phase of the estuary. 
With the exception of Stn U, chl a concentrations of both surface and bottom phytoplankton decreased markedly during the closed phase (from 8.6 to $1.9 \mathrm{mg}$ $\mathrm{m}^{-3}$ and from 8.6 to $1.5 \mathrm{mg} \mathrm{m}^{-3}$, respectively: Fig. 6). The opening of the estuary led to a sudden increase in phytoplankton biomass, with a maximum value of

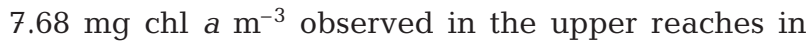
November 1999. Thereafter, phytoplankton chl a concentrations varied between 0.09 and $2.64 \mathrm{mg} \mathrm{m}^{-3}$. A 1 -way ANOVA revealed a significant sampling date effect on both surface and bottom phytoplankton chl a (surface: $F_{11,24}=18.6, \mathrm{p}<0.01$; bottom: $F_{11,24}=20.9$, $\mathrm{p}<0.01)$.

Microphytobenthic chl a concentrations varied widely in the Mdloti Estuary, from 75 (Stn L, August 1999) to $480 \mathrm{mg} \mathrm{m}^{-2}$ (Stn U, July 1999) during the closed phase, and from 1.42 (Stn U, January 2000) to $198 \mathrm{mg} \mathrm{m}^{-2}$ (Stn U, November 1999) during the open phase (Fig. 7). A 2-way ANOVA, performed on $\log _{10}$-transformed chl a values, revealed a significant interaction between sampling dates and stations $\left(F_{22,72}=2.31, \mathrm{p}<0.01\right)$ as well as significant variations between stations $\left(F_{2,72}=\right.$ 8.53, $\mathrm{p}<0.01)$ and dates $\left(F_{11,72}=29.6, \mathrm{p}<0.01\right)$. Stn $\mathrm{L}$ had the lowest mean benthic microalgal biomass

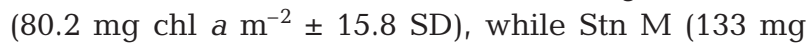
chl $\left.a \mathrm{~m}^{-2} \pm 24.8 \mathrm{SD}\right)$ and Stn U (203 mg chl $a \mathrm{~m}^{-2} \pm$ 52.2 SD) exhibited similar amounts. Although there was a significant date effect, only Stn U showed a marked fluctuation, with a decrease in microphytobenthic chl a concentration during the open $(54.2 \mathrm{mg} \mathrm{chl} a$ $\mathrm{m}^{-2} \pm 29.9 \mathrm{SD}$ ) compared to the closed (352 mg chl a $\mathrm{m}^{-2} \pm 47.3 \mathrm{SD}$ ) phase of the estuary (Fig. 7).

Throughout the survey, microphytobenthic chl a values were consistently 1 to 2 orders of magnitude higher than vertically-integrated water column chl a concentrations. The only exception to this pattern was in
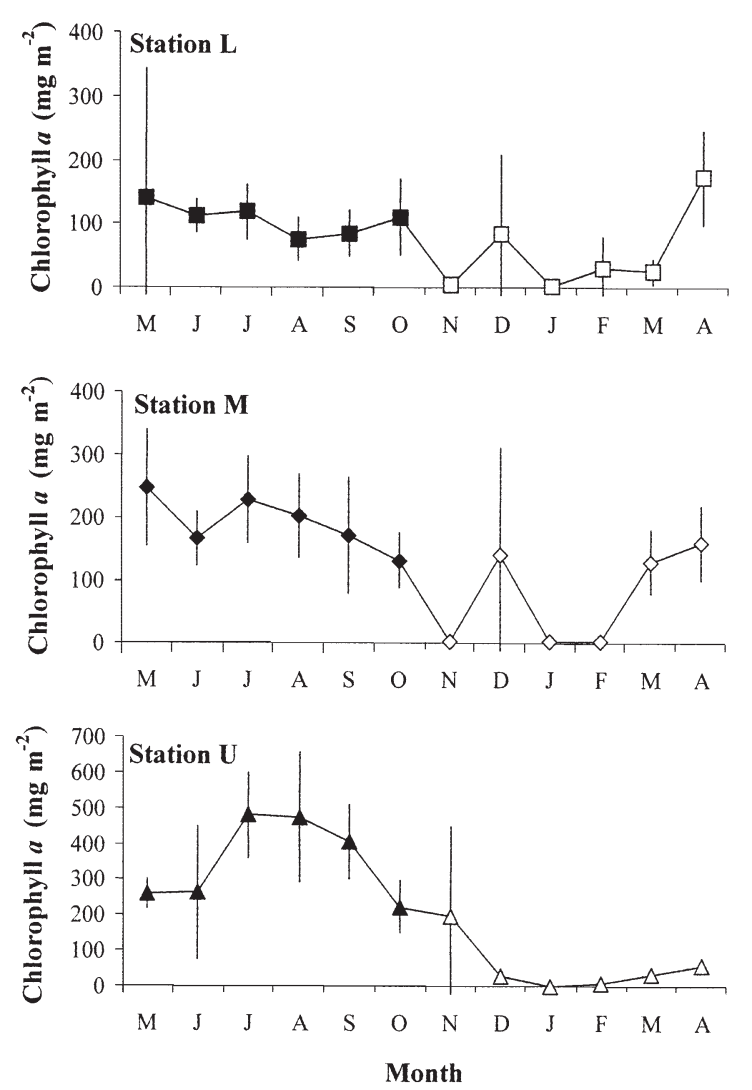

Fig. 7. Temporal variations in microphytobenthic biomass (average \pm SD) at Stns L, M, and U in the Mdloti Estuary. Symbols as in Fig. 3

November at Stn M (Table 1). On the other hand, the relative areal concentrations of microphytobenthic and phytoplankton chl a did not differ significantly

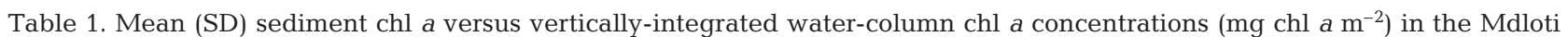
Estuary, May 1999 to April 2000. Sediment to water-column chl a ratio is also indicated. L: lower reaches; M: middle reaches; U: upper reaches

\begin{tabular}{|c|c|c|c|c|c|c|c|c|c|}
\hline Month & Sediment & $\begin{array}{c}\text { Stn L } \\
\text { Water column }\end{array}$ & Ratio & Sediment & $\begin{array}{c}\text { Stn M } \\
\text { Water column }\end{array}$ & Ratio & Sediment & $\begin{array}{c}\text { Stn U } \\
\text { Water column }\end{array}$ & Ratio \\
\hline May 1999 & $139.5(204.3)$ & 19.4 & 7.2 & 248.1 (93) & 17 & 146 & $261.1(41.7)$ & 3.4 & 76.7 \\
\hline Jun 1999 & $113.1(25.6)$ & 17.1 & 6.6 & $166.9(43.4)$ & 9.2 & 18.1 & $263.8(186.6)$ & 4.0 & 66.5 \\
\hline Jul 1999 & $118.9(43.6)$ & 12.3 & 9.7 & 229.9 (69) & 11.2 & 20.5 & 480.3 (121.2) & 5.0 & 95.5 \\
\hline Aug 1999 & 75 (33.9) & 9.7 & 7.7 & $202.5(66.3)$ & 7.4 & 27.4 & $475.2(183)$ & 2.5 & 190.2 \\
\hline Sep 1999 & $85.2(36.3)$ & 2.9 & 29.2 & $171.6(93)$ & 3.3 & 51.5 & $407.3(104.2)$ & 1.5 & 267.8 \\
\hline Oct 1999 & $110.5(59.8)$ & 6.0 & 18.4 & $132.8(43.5)$ & 5.2 & 25.2 & $223.9(72)$ & 4.6 & 48.3 \\
\hline Nov 1999 & $5.4(2.6)$ & 3.2 & 1.7 & $5.6(3.9)$ & 3.6 & 0.6 & $198.3(251.4)$ & 4.6 & 43.0 \\
\hline Dec 1999 & $84(125.4)$ & 0.5 & 166.1 & $141.7(170.4)$ & 0.7 & 206.8 & $27.8(14.6)$ & 0.2 & 122.1 \\
\hline Jan 2000 & $1.6(1.0)$ & 0.1 & 30.2 & $1.6(0.8)$ & 0.1 & 11.4 & $1.4(0.5)$ & 0.1 & 16.1 \\
\hline Feb 2000 & $31.5(47.3)$ & 0.2 & 207.4 & $3.3(2.1)$ & 0.1 & 51.4 & $7.3(5.4)$ & 0.2 & 32.5 \\
\hline Mar 2000 & 25.1 (19.9) & 0.4 & 70.9 & $129.1(51.6)$ & 1.1 & 122.2 & $33.3(14.7)$ & 0.7 & 50.9 \\
\hline Apr 2000 & $172.3(73.8)$ & 0.6 & 285.7 & $159.8(58.7$ & 0.2 & 672.6 & $57.1(17.8)$ & 0.2 & 242.9 \\
\hline
\end{tabular}


Table 2. Rank correlation coefficients between rainfall and physical-chemical variables in the Mdloti Estuary. Number of observations, $\mathrm{n}=12$. "Significant at $0.01<\mathrm{p} \leq 0.05$. $K_{\mathrm{d}}$ : vertical attenuation coefficient

\begin{tabular}{|lc|}
\hline Variable & Rainfall \\
\hline$K_{\mathrm{d}}$ & $0.59^{*}$ \\
DIN (surface) & $0.62^{*}$ \\
DIP (surface) & $0.45^{*}$ \\
DIN (bottom) & $0.58^{*}$ \\
DIP (bottom) & -0.16 \\
\hline
\end{tabular}

between the closed and open phases of the estuary (Mann-Whitney U-test, p > 0.05).

Surface and bottom DIN concentrations in the Mdloti Estuary showed seasonal variations, with lowest values during the winter closed phase (Fig. 8A). DIN concentrations varied between 0.5 and $14.3 \mu \mathrm{M}$ during the closed phase and between 6.6 and $204 \mu \mathrm{M}$ during the open phase. Conversely, neither surface nor bottom DIP concentrations exhibited any seasonal trend in the estuary (Fig. 8B). DIP ranged from 0.6 to $5.5 \mu \mathrm{M}$ during the closed phase and from 0.3 to $5.8 \mu \mathrm{M}$ during the open phase. DIN:DIP molar ratios were used to test for potential limiting effects of nutrients on microalgal biomass (Howarth 1988). Seasonal variations in surface as well as bottom DIN:DIP ratios were much greater than variations in DIN values in the Mdloti Estuary (Fig. 8C). During the closed phase, DIN:DIP values were well below the Redfield ratio of 16:1 (Redfield et al. 1963). Conversely, with the exception of Stns M and U in November 1999, DIN:DIP ratios were usually well above 16 during the open phase.

Light attenuation in the estuary showed a highly significant and positive relationship with rainfall, obviously reflecting the increase in turbidity as a result of runoff from the catchment area (Table 2). Likewise, rainfall showed a positive relationship with surface and bottom DIN as well as surface DIP, thereby suggesting increased loading of nutrients (and/or less utilization of these nutrients by phytoplankton) during the open phase of the estuary. Partial correlation analysis showed that both surface and bottom phytoplankton chl a concentrations were inversely correlated with rainfall (Table 3). Also, bottom phytoplankton exhibited a positive relationship with $K_{\mathrm{d}}$. However, in contrast to phytoplankton, microphytobenthic chl a concentration was not correlated with any of these variables.

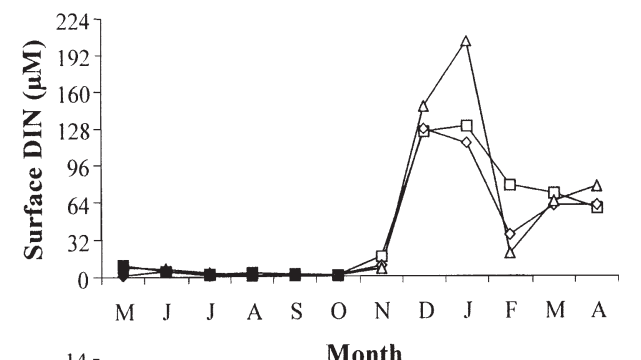

A
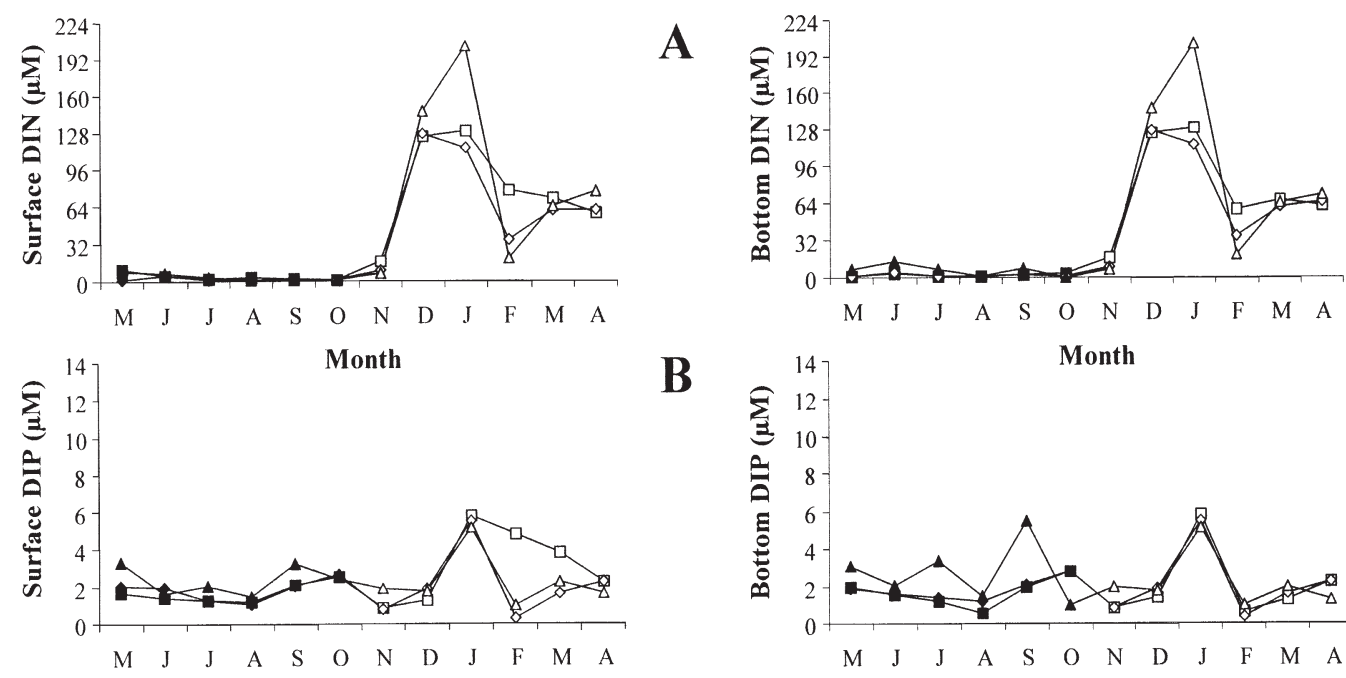

B
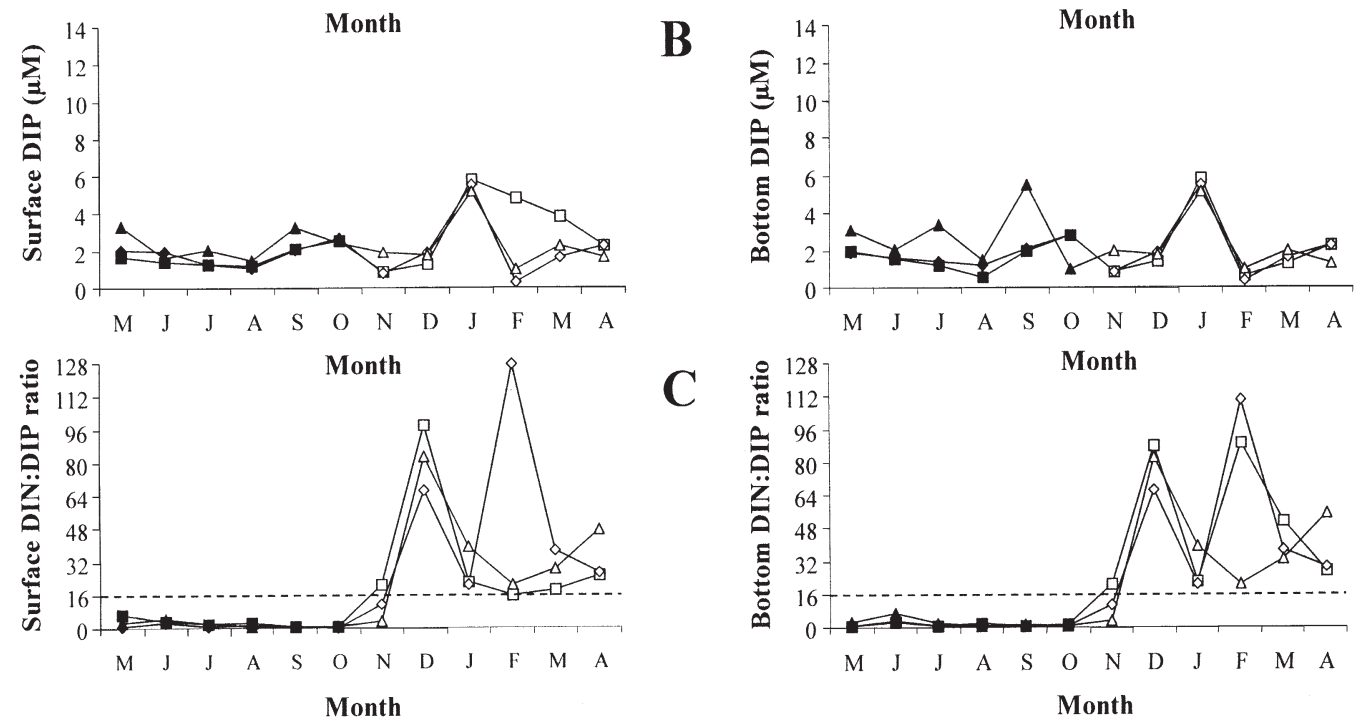

Fig. 8. Temporal variations in surface and bottom DIN (A), DIP (B), and DIN:DIP ratios (C) at Stns L, M and U in the Mdloti Estuary. Symbols as in Fig. 3 


\section{DISCUSSION}

Several studies dealing with microphytobenthos have highlighted their significant role as primary producers in shallow-water ecosystems (Mallin et al. 1992, MacIntyre et al. 1996, Barranguet 1997). In shallow aquatic ecosystems, microphytobenthos contributes a significant fraction of the total primary production and biomass, equaling or even exceeding that of phytoplankton in the overlying water column (Cadée \& Hegeman 1974a,b, Lukatelich \& McComb 1986, Fielding et al. 1988, Kromkamp et al. 1995, Adams et al. 1999, Cahoon 1999, Perissinotto et al. 2001). In the Mdloti Estuary, much higher levels of chl a were recorded in the top first centimeter of surface sediment than in the overlying water column (with the exception of November 1999: Table 1). This difference ranged from 1 to 2 orders of magnitude, resulting in an average ratio of water column to sediment chl $a$ of $0.08 \pm 0.09 \mathrm{SD}$. Similar results have been reported for other South African temporarily-open estuaries (Adams et al. 1999, Perissinotto et al. 2001).

The microphytobenthic biomass of the Mdloti Estu-

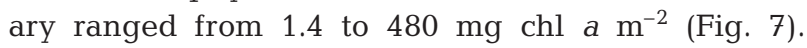
These values are comparable to those found by Perissinotto et al. (2001) for the Mpenjati Estuary (19.6 to $616 \mathrm{mg} \mathrm{chl} a \mathrm{~m}^{-2}$ ), but greater than those reported by Adams et al. (1999) for the Great Brak Estuary (85 to $297 \mathrm{mg} \mathrm{chl} \mathrm{a} \mathrm{m}{ }^{-2}$ ). Also, as in the Mpenjati study (Perissinotto et al. 2001), the highest microphytobenthic biomass occurred during the closed phase. These values are among the highest reported in the literature (MacIntyre et al. 1996, Light \& Beardall 1998, Adams et al. 1999, Cahoon et al. 1999, Perissinotto et al. 2000, 2001, Snow et al. 2000a,b) and are in the range of maximum estimates of sediment chl a values reported from the 0 to $5 \mathrm{~m}$ depth range of tropical/ subtropical areas (Cahoon 1999). Comparisons with other estuaries are however difficult, especially when dealing with tidally-driven systems where lower benthic microalgal biomass may be the result of strong currents and wave action. The structure of the sediment will also affect microalgal biomass levels, with generally highest values obtained from muddy rather than sandy sediments (Adams et al. 1999), although on a number of occasions, the opposite has also been recorded (see Cahoon et al. 1999). A preliminary analysis of the sediment structure of the Mdloti Estuary shows that this is predominantly sandy throughout the estuary and for most of the year (C.N. pers. obs.).
The phytoplankton biomass of the Mdloti Estuary

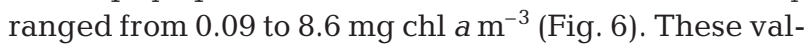
ues are lower than those measured in permanentlyopen estuaries, where maximum levels often exceed

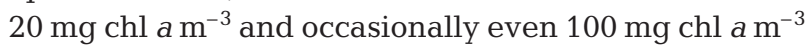
(Adams et al. 1999). On the other hand, they are comparable to concentrations reported by Adams et al. for the Great Brak Estuary (0.2 to $13.3 \mathrm{mg} \mathrm{chl} \mathrm{a} \mathrm{m}^{-3}$ ) and by Perissinotto et al. (2001) for the Mpenjati Estuary ( 0.14 to $15.4 \mathrm{mg} \mathrm{chl} \mathrm{a} \mathrm{m}^{-3}$ ). Both these systems are also temporarily-open and located along the east coast of South Africa.

The intensity of light and/or the concentration of macronutrients are key factors limiting microalgal growth in aquatic environments in general (Dugdale 1967, Droop et al. 1982, Tett et al. 1985) and estuaries in particular (Cloern 1987, Malone et al. 1988). Tropical estuarine systems experience relatively short-lived flood events that contribute substantially to their annual nutrient budget as well as to sediment particle loading (Eyre \& Balls 1999). This situation is very similar to that observed in temporarily-open estuaries.

The closed phase of the Mdloti Estuary was characterized by low rainfall (Fig. 2) and low $K_{\mathrm{d}}$ values (Fig. 3). It would be expected that more favourable underwater light conditions for photosynthesis would result in an increase in phytoplankton biomass during the closed phase. Contrary to this, phytoplankton chl a concentrations actually decreased from 8.6 to $1.5 \mathrm{mg}$ $\mathrm{m}^{-3}$ during this period. It must be recalled, however, that during the closed phase DIN:DIP molar ratios were well below the Redfield ratio of 16:1 (Fig. 8C), indicating potential N-limitation of phytoplankton growth. It can be suggested, therefore, that the period of low rainfall which led to low river inflow, increased water clarity, and reduced nutrient loading would have increased the likelihood of nutrient- rather than light-limitation during the closed phase of the Mdloti Estuary.

Hydrology, particularly the strong freshwater inflow during the rainy season, played an important role not 
only in the physical and chemical environment but also in the biology of the Mdloti Estuary. Flushing, for instance, would have contributed occasionally to low phytoplankton biomass in the estuary immediately after strong runoff events (Adams et al. 1999). Heavy rainfall and increased river flow dominated the open phase of the estuary and resulted not only in a dramatic decrease in water clarity and euphotic depth (Fig. 5), but also in an increase in nutrient loading. High DIN and DIP concentrations usually stimulate algal growth (Fisher et al. 1992, Gallegos \& Jordan 1997). One month after the opening of the estuary, DIN:DIP ratios were well above the Redfield ratio of 16:1 (Fig. 8C), suggesting that DIP was indeed the element in shortest supply with respect to nutrient requirements of phytoplankton. Although nutrients were present in high concentrations throughout the open phase, phytoplankton could not attain maximum biomass levels because increased turbidity in the estuary during that period would probably have inhibited primary production. Because of this high turbidity, phytoplankton would have spent a considerable part of the daytime in the dark, thereby increasing respiratory losses (Legendre 1990).

A number of studies have reported seasonal fluctuations in microphytobenthic standing stocks (Montagna et al. 1983, Gould \& Gallagher 1990, Pinckney \& Zingmark 1993), while others have not found any significant differences between seasons (Cadée \& Hegeman 1974b, Colijn \& de Jonge 1984, de Jonge \& Colijn 1994). Seasonal fluctuations in microphytobenthic biomass were indeed observed during this study of the Mdloti Estuary (Fig. 7). The standing stock of benthic microalgae is regulated by different factors, such as nutrient availability, irradiance, and sediment characteristics (MacIntyre et al. 1996, Cahoon et al. 1999, Underwood \& Kromkamp 1999). In the Mdloti, microphytobenthic chl a concentration was not related to the nutrient concentration in the overlying water (Table 3). These results agree with those of Gruendling (1971), Lukatelich \& McComb (1986), and Roux et al. (2001), who reported that nutrient concentrations in the water overlying the sediment were not important in controlling microphytobenthic biomass. Nutrient concentrations at the sediment surface were not measured during this study, but such measurements are clearly warranted in future studies. Because of high rates of remineralization within the sediment, growth of shallow-water microphytobenthos is generally not limited by inorganic nutrients (Admiraal et al. 1982, Nilsson et al. 1991, Sundbäck et al. 1996). While this appears to be true for nutrient-rich muddy estuaries, in many sandy sediments nutrient limitation does seem to occur, with biomass responding positively to nutrient addition (Underwood \& Kromkamp 1999).
Light flux to the sediment-water interface is a critical factor for benthic microalgal growth and is a function of depth and turbidity (Cahoon 1999). Cahoon (p. 68) reported, however, that 'benthic microalgae are capable of sustaining growth at very low light intensities, in

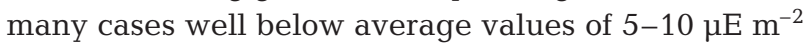
$\mathrm{s}^{-1}$ and $1 \%$ surface incident radiation'. In the Mdloti Estuary, with 1 exception (February 2000), benthic microalgae always met the theoretical minimum light intensity of $0.1 \%$ of surface incident flux required to support growth (Falkowski 1988). Thus, light may not have limited benthic primary production during the period of this study. Indeed, microphytobenthic biomass was not related to the percentage of incident light reaching the bottom during the open phase $(\mathrm{r}=$ $-0.15, p>0.05)$. The question of whether the light intensity reaching the sediment was sufficient to support benthic primary production needs, however, to be addressed in future studies. It is also possible that some microalgae living within the sediment may not have access to even the lowest levels of irradiance necessary for primary production. In this case they may actually be able to grow only when resuspended in the water column.

Loading of fine sediment to shallow waters are known to inhibit benthic microalgal production and biomass. This can be due partly to an increase in turbidity, but also to changes in physical, chemical and biological properties of the sediment-water interface as these sediments settle out of the water column (Cahoon et al. 1999). Also, an increased percentage of fine or very fine sediments enhances these negative effects on benthic microalgal biomass (Cahoon et al. 1999). The increase in river runoff during the open phase of the Mdloti Estuary led to an increase in $K_{\mathrm{d}}$, and increased the loading of fine sediments in the estuary. Whether such loading had the effect of modifying the sediment composition of the estuary and causing a decrease in the biomass of benthic microalgae is not known, and should be considered in future investigations in the area. The results of the partial correlation analysis (Table 3) indicate that benthic microalgal biomass may be less vulnerable than phytoplankton biomass to changes in physico-chemical and biological parameters associated with the alternation of open and closed phases in this type of estuary. The recent escalation in soil disturbance arising from agricultural activities in the area is, however, dramatically increasing the silt loading of these estuaries (Cooper et al. 1999). If this process is not controlled adequately, it could soon impact negatively on this key and primary source of production. Since benthic microalgae are an important food source for meiobenthos (Blanchard 1991, Montagna 1995, Buffan-Dubau \& Carman 2000) and demersal zooplankton (Perissinotto et al. 2000), 
this would have important negative consequences for the entire food web of this type of estuary.

Acknowledgements. This study was funded through a Joint Venture Project between the National Research Foundation (NRF, Pretoria) and the Department of Environmental Affairs \& Tourism (DEA\&T). We wish to thank the Research Section of Kwazulu-Natal Wildlife for granting research permits and for providing logistical support. D. Watt of the South African Sugar Association Experiment Station (Mt Edgecombe, Durban) and G. Swart of the South African Weather Bureau (Pretoria) are thanked for providing rainfall data. We are also very grateful to a number of students, including I. Kibirige, C. Ouellet and S. Proches for their invaluable help with field work and laboratory analyses.

\section{LITERATURE CITED}

Adams J, Bate G, O'Callaghan M (1999) Primary producers. In: Allanson BR, Baird D (eds) Estuaries of South Africa. Cambridge University Press, Cambridge, p 91-117

Admiraal W, Peletier H, Zomer H (1982) Observations and experiments on the population of epipelic diatoms of an estuarine mudflat. Estuar Coast Shelf Sci 14:471-487

Allanson BR, Baird D (1999) Fifteen years on! Or one hundred and fifty years on! In: Allanson BR, Baird D (eds) Estuaries of South Africa. Cambridge University Press, Cambridge, p 1-3

Allanson BR, Baird D, Heydorn A (1999) Perspectives. In: Allanson BR, Baird D (eds) Estuaries of South Africa. Cambridge University Press, Cambridge, p 321-327

Barranguet C (1997) The role of microphytobenthic primary production in a Mediterranean mussel culture area. Estuar Coast Shelf Sci 44:753-765

Begg GW (1984) The estuaries of Natal. Part 2. Natal Town and Regional Planning Report 55. The Natal Town and Regional Planning Commission, Pietermaritzburg, South Africa

Blaber SJM, Hay DG, Cyrus DP, Martin TJ (1984) The ecology of two degraded estuaries on the north coast of Natal, South Africa. S Afr J Zool 19:224-240

Blanchard GF (1991) Measurements of meiofauna grazing rates on microphytobenthos: is primary production a limiting factor? J Exp Mar Biol Ecol 147:37-46

Buffan-Dubau E, Carman KR (2000) Diel feeding behavior of meiofauna and their relationships with microalgal resources. Limnol Oceanogr 45:381-395

Cadée GC, Hegeman J (1974a) Primary production of phytoplankton in the Dutch Wadden Sea. Neth J Sea Res 8: 240-259

Cadée GC, Hegeman J (1974b) Primary production of the benthic microflora living on tidal flats in the Dutch Wadden Sea. Neth J Sea Res 8:260-291

Cahoon LB (1999) The role of benthic microalgae in neritic ecosystems. Oceanogr Mar Biol Annu Rev 37:47-86

Cahoon LB, Nearhoof JE, Tilton CL (1999) Sediment grain size effect on benthic microalgal biomass in shallow aquatic ecosystems. Estuaries 22:735-741

Cloern JE (1987) Turbidity as a control on phytoplankton biomass and productivity in estuaries. Cont Shelf Res 7 : 1367-1381

Colijn F, de Jong VN (1984) Primary production of microphytobenthos in the Ems-Dollard estuary. Mar Ecol Prog Ser 14:185-196
Cooper A, Wright I, Mason T (1999) Geomorphology and sedimentology. In: Allanson BR, Baird D (eds) Estuaries of South Africa. Cambridge University Press, Cambridge, p 5-25

Day JH (1981) Estuarine ecology with particular reference to southern Africa. AA Balkema, Cape Town

de Jonge VN, Colijn F (1994) Dynamics of microphytobenthos biomass in the Ems estuary. Mar Ecol Prog Ser 104: 185-196

de Villiers C, Hodgson A, Forbes A (1999) Studies on estuarine macroinvertebrates. In: Allanson BR, Baird D (eds) Estuaries of South Africa. Cambridge University Press, Cambridge, p 167-207

Droop MR, Mickelson MJ, Scott JM, Turner MF (1982) Light and nutrient status of algal cells. J Mar Biol Assoc UK 62: 403-434

Dugdale RC (1967) Nutrient limitation in the sea: dynamics, identification, and significance. Limnol Oceanogr 12: 685-695

Eyre B, Balls P (1999) A comparative study of nutrient behavior along the salinity gradient of tropical and temperate estuaries. Estuaries 22:313-326

Falkowski PG (1988) Theoretical calculation of the depth of the euphotic zone in the sea. In: Agegian C (ed) Biogeochemical cycling and fluxes between the deep euphotic zone and other ocean realms. National Undersea Research Program, Rockville, MD, p 379-384 (National Undersea Research Program Report No. 88)

Fielding PJ, Damstra KJ, Branch GM (1988) Benthic diatom biomass, production and sediment chlorophyll in Langebaan Lagoon, South Africa. Estuar Coast Shelf Sci 27: 413-426

Fisher TR, Peele ER, Ammerman JW, Harding LW (1992) Nutrient limitation of phytoplankton in Chesapeake Bay. Mar Ecol Prog Ser 82:51-63

Forbes AT, Niedinger S, Demetriades NT (1994) Recruitment and utilisation of nursery grounds by penaeid prawn postlarvae in Natal, South Africa. In: Dyer KR, Orth RJ (eds) Changes in fluxes in estuaries. Olsen \& Olsen, Frendensborg, p 379-384

Gallegos CL, Jordan TE (1997) Seasonal progression of factors limiting phytoplankton pigment biomass in the Rhode River estuary, Maryland (USA). II. Modeling N versus P limitation. Mar Ecol Prog Ser 161:199-212

Gould D, Gallagher E (1990) Field measurement of specific growth rate, biomass, and primary production of benthic diatoms of Savin Hill Cove, Boston. Limnol Oceanogr 35: $1757-1770$

Gruendling GK (1971) Ecology of the epipelic algal communities in Marion Lake, British Columbia. J Phycol 7:239-249

Howarth RW (1988) Nutrient limitation of net primary production in marine ecosystems. Annu Rev Ecol Syst 19: 89-110

Kirk JTO (1983) Light and photosynthesis in aquatic ecosystems. Cambridge University Press, Cambridge

Kromkamp J, Peene J, Rijswijk PV, Sandee A, Goosen N (1995) Nutrients, light and primary production by phytoplankton and microphytobenthos in the eutrophic, turbid Westerschelde estuary (The Netherlands). Hydrobiologia 311:9-19

Legendre L (1990) The significance of microalgal blooms for fisheries and for the export of particulate organic carbon in oceans. J Plankton Res 12:681-699

Light BR, Beardall J (1998) Distribution and spatial variation of benthic microalgal biomass in a temperate, shallowwater marine system. Aquat Bot 61:39-54

Lukatelich RJ, McComb AJ (1986) Distribution and abun- 
dance of benthic microalgae in a shallow southwestern Australian estuarine system. Mar Ecol Prog Ser 27: 287-297

MacIntyre HL, Geider RJ, Miller DC (1996) Microphytobenthos: the ecological role of the 'secret garden' of unvegetated, shallow-water marine habitats. I. Distribution, abundance and primary production. Estuaries 19: 186-201

Mallin MA, Burkholder JM, Sullivan MJ (1992) Contributions of benthic microalgae to coastal fishery yield. Trans Am Fish Soc 121:691-695

Malone TC, Crocker LH, Pike SE, Wendlerm BW (1988) Influences of river flow on the dynamics of phytoplankton production in a partially stratified estuary. Mar Ecol Prog Ser 48:235-249

Miller DC, Geider RJ, MacIntyre HL (1996) Microphytobenthos: the ecological role of the 'secret garden' of unvegetated, shallow-water marine habitats. II. Role in sediment stability and shallow-water food webs. Estuaries 19: 202-212

Montagna P (1995) Rates of metazoan meiofaunal microbivory: a review. Vie Milieu 45:1-9

Montagna P, Coull B, Herring T, Dudley B (1983) The relationship between abundances of meiofauna and their suspected microbial food (diatoms and bacteria). Estuar Coast Shelf Sci 17:381-394

Morant P, Quinn N (1999) Influence of man and management of South African estuaries. In: Allanson BR, Baird D (eds) Estuaries of South Africa. Cambridge University Press, Cambridge, p 289-320

Mortazavi B, Iverson RL, Landing WM, Lewis FG, Huang W (2000) Control of phytoplankton production and biomass in a river-dominated estuary: Apalachicola Bay, Florida, USA. Mar Ecol Prog Ser 198:19-31

Mostert SA (1983) Procedure used in South Africa for the automatic photometric determination of micronutrients in seawater. S Afr J Mar Sci 1:189-198

Nilsson P, Jönsson B, Swanberg IL, Sundbäck K (1991) Response of a marine shallow-water sediment system to an increased load of inorganic nutrients. Mar Ecol Prog Ser 71:275-290

Perissinotto R, Walker DR, Webb P, Wooldridge TH, Bally R (2000) Relationships between zoo- and phytoplankton in a warm-temperate, semi-permanently closed estuary, South Africa. Estuar Coast Shelf Sci 51:1-11

Perissinotto R, Nozais C, Kibirige I (2001) Spatio-temporal variations in phytoplankton and microphytobenthic bio-

Editorial responsibility: Otto Kinne (Editor),

Oldendorf/Luhe, Germany mass in a South African temporarily-open estuary. Estuar Coast Shelf Sci (in press)

Pinckney J, Zingmark RG (1993) Biomass and production of benthic microalgal communities in estuarine habitats. Estuaries 16:887-897

Reddering JSV, Rust IC (1990) Historical changes and sedimentary characteristics of southern African estuaries. S Afr J Sci 86:425-428

Redfield A, Ketchum B, Richards F (1963) The influence of organisms on the composition of sea-water. In: Hill M (ed) The sea. Interscience, New York, p 26-77

Rodriguez FDG (1993) The determination and distribution of microbenthic chlorophyll-a in selected south Cape estuaries. MSc thesis, University of Port Elizabeth

Roux R, Gosselin M, Desrosiers G, Nozais C (in press) Effects of reduced ultraviolet radiation on a microbenthic community during an 11-week microcosm experiment. Mar Ecol Prog Ser

Snow GC, Adams JB, Bate GC (2000a) Effects of river flow on estuarine microalgal biomass and distribution. Estuar Coast Shelf Sci 51:255-266

Snow GC, Bate GC, Adams JB (2000b) The effect of a single freshwater release into the Kromme Estuary. 2. Microalgal response. Water SA (Pretoria) 26:301-310

Sundbäck K, Carlson L, Nilsson C Jönsson B, Wulff A, Odmark S (1996) Response of benthic microbial mats to drifting green algal mats. Aquat Microb Ecol 10:195-208

Tett P, Heaney SI, Droop MR (1985) The Redfield ratio and phytoplankton growth rate. J Mar Biol Assoc UK 65:487-504

Underwood GJC, Kromkamp J (1999) Primary production by phytoplankton and microphytobenthos in estuaries. Adv Ecol Res 29:93-153

Walker DR, Perissinotto R, Bally R (in press) Phytoplankton dynamics in the Nyara estuary, a small temporarily open system in the Eastern Cape (South Africa). Afr J Aquat Sci

Welschmeyer NA (1994) Fluorometric analysis of chlorophyll $a$ in the presence of chlorophyll $a$ and pheopigments. Limnol Oceanogr 39:1985-1992

Whitfield AK (1992) A characterization of southern African estuarine systems. S Afr J Aquat Sci 18:89-103

Whitfield AK (1995) Available scientific information on individual South African estuarine systems. Water Research Commission Report No. 577/1/95. Water Research Commission, Pretoria

Whitfield AK, Marais H (1999) The ichthyofauna. In: Allanson BR, Baird D (eds) Estuaries of South Africa. Cambridge University Press, Cambridge, p 209-233

Submitted: October 27, 2000; Accepted: March 27, 2001

Proofs received from author(s): November 12, 2001 